\title{
Zdrowie człowieka i przyczyny jego utraty według antropologii prawosławnej
}

\author{
ks. Piotr Pietkiewicz
}

\author{
Białystok, Polska \\ kspietkiewicz@poczta.onet.pl
}

rev. P. Pietkiewicz, Man's health and causes of its loss according to the Orthodox anthropology, Elpis, 20 2018: $253-257$.

\begin{abstract}
The state of man's health is a multidimensional notion and a dynamic phenomenon changing with time. Describing a man as healthy we mean that the person in question is in a state of relative stabilisation and interior harmony of various spheres of his being: physical, psychological and spiritual. The notion of man's health, existing in the Orthodox anthropology, is inseparable from the state of human nature that the first man - Adam - was given. The latter was supposed to lead or rather develop it, in synergy of his free will with the grace of God, to perfection. The Christian way of experiencing and living with illnesses is full of humility, patience and hope in God. Faith helps to understand and make the illness meaningful. A believing man sees the period of loss of health as a time of trial and conversion, when through repentance one can renew his relationship with God. State of health is an aim that can be achieved only in the perspective of eternity and as such should be a subject of continuous commitment and unceasing care of all the people.

Streszczenie: Stan zdrowia człowieka jest pojęciem wielowymiarowym oraz zjawiskiem dynamicznym, zmieniającym się w czasie. Określając człowieka zdrowym, należy przez to rozumieć, że dana osoba znajduje się w stanie względnej stabilizacji i harmonii wewnętrznej różnych sfer: fizycznej, psychicznej i duchowej. Pojęcie zdrowia człowieka, funkcjonujące w prawosławnej antropologii, jest nierozerwalnie związane ze stanem natury ludzkiej, jaką obdarzony został pierwszy człowiek - Adam i którą miał on doprowadzić, w synergii jego wolnej woli z Bożą łaską, do doskonałości. Chrześcijański sposób przeżywania chorób cechuje pokora, cierpliwość oraz pokładanie nadziei w Bogu. Wiara pomaga zrozumieć i nadać sens chorobie. Człowiek wierzący postrzega okres utraty zdrowia jako czas próby i nawrócenia, w którym droga pokajania może odnowić swą relację z Bogiem. Stan zdrowia jest celem osiągalnym dopiero w perspektywie wieczności i jako taki powinien być przedmiotem stałego zaangażowania i nieustannej troski wszystkich ludzi.
\end{abstract}

Keywords: health, man, Orthodox anthropology, illness, sin

Słowa kluczowe: zdrowie, człowiek, antropologia prawosławna, choroba, grzech

Zdrowie to termin nie tylko medyczny, ale również filozoficzny oraz teologiczny. Poczucie zdrowia jest sprawą bardzo indywidualną każdego człowieka, dlatego sformułowanie jednej definicji zdrowia jest rzeczą niezwykle trudną.

Pierwszą z takich prób podjął Hipokrates z Kos (460377 p.n.e.) nazywany „ojcem medycyny”. Według niego zdrowie charakteryzuje się dobrym samopoczuciem i wynika $\mathrm{z}$ równowagi między człowiekiem a otaczającym go środowiskiem życia ${ }^{1}$. Platon (437-347 p.n.e.) uznawał zdrowie za najważniejsze dobro i traktował jako cel doskonalenia stylu życia. Epikur (341-270 p.n.e.) postrzegał je jako stan pełnego zaspokojenia wszystkich życiowych potrzeb. Natomiast stoicy (III p.n.e.) zdrowie uzależniali od wysokiego poziomu życia moralnego i przezwyciężenia cierpienia.

Encyklopedia medycyny pojęcie zdrowia interpretuje jako stan pełnej sprawności fizycznej, psychicznej i społecznej. W węższym zaś znaczeniu, to nieobecność choroby lub kalectwa². Według Światowej Organizacji Zdrowia

\footnotetext{
Por. J. Fijałek, Społeczne tradycje organizacyjne i naukowe w opiece zdrowotnej do końca XVIII wieku, [w:] Historia medycyny, T. Brzeziński (red.), , Warszawa 1995, s. 213- 214.

2 T. Rożniatowski, Mała encyklopedia medycyny, Warszawa 1982,
}

o zdrowiu stanowi nie tylko brak choroby, lecz pełny fizyczny, psychiczny i społeczny dobrostan.

Wśród naukowców XX wieku R. J. Dubois zdrowie określa jako zespół cech pozytywnych, pozwalających człowiekowi na wykorzystanie wszelkich możliwości twórczych oraz osiągnięcie siły i szczęścia. M. Kacprzak zdrowie postrzega jako proces dynamiczny, od którego zależy dobre samopoczucie oraz taki stopień przystosowania się biologicznego i społecznego do środowiska, jaki jest osiągalny dla danej jednostki w najkorzystniejszych warunkach. Dla R. Bures zdrowie to system wzajemnych uwarunkowań w relacji organizm-środowisko, rzutujący na potencjał zdolności przystosowania się organizmu do wymogów środowiska i wyposażający organizm w dyspozycję do utrzymania równowagi pomiędzy nim a wymogami środowiska ${ }^{3}$.

Stan zdrowia człowieka jest pojęciem wielowymiarowym oraz zjawiskiem dynamicznym, zmieniającym się w czasie. Dlatego określając człowieka zdrowym, należy przez to rozumieć, że dana osoba znajduje się w stanie

3 Zob. I. D. Karwat i in., Zdrowie i niepetnosprawność - problemy $w$ definiowaniu. Cz. 1. Cechy wykorzystywane $w$ ocenie stanu zdrowia, „Journal of Health Sciences” 2012; (2)5, s. 90-92.
} 
względnej stabilizacji i harmonii wewnętrznej różnych sfer: fizycznej, psychicznej i duchowej. Ten dobrostan podlega ciągłym życiowym przemianom, czyniąc starania prozdrowotne nieustannie aktualnymi.

W większości pośród blisko 350 badań w USA dotyczących zdrowia fizycznego i 850 badań zdrowia psychicznego, które wykorzystały zmienne religijne i duchowe, odkryto, że religijność i duchowość wpływają na lepsze wyniki zdrowia ${ }^{4}$. Badania te potwierdziły, że religijne zaangażowanie jest związane z mniejszą zapadalnością i łagodniejszym przebiegiem chorób układu krążenia, z niższym ciśnieniem i mniejszym nadciśnieniem. Osoby religijne bardziej podporządkowują się zaleceniom lekarskim i zachowaniom promującymi zdrowie. Wyniki badań sugerują także, że osoby wierzące bardziej akceptują śmierć i przeżywają ją z mniejszym lękiem, a nieuleczalnie chorzy z przekonań religijnych czerpią siły i nadzieję do walki z chorobami. Wysoka religijność wiąże się z mniejszym ryzykiem depresji oraz z szybszym powrotem do zdrowia psychicznego. Osoby religijne mniej nadużywają alkoholu i różnych substancji psychoaktywnych. W porównaniu z osobami niereligijnymi, ludzie aktywni religijnie mają silniejszy system immunologiczny. Jak wynika z badań związek między religijnością a lepszymi wynikami zdrowotnymi wydaje się oczywisty. Są to ważne argumenty, dla których lekarz powinien uznawać i wspierać duchowość pacjenta.

Pojęcie zdrowia człowieka, funkcjonujące w prawosławnej antropologii, jest nierozerwalnie związane ze stanem natury ludzkiej, jaką obdarzony został pierwszy człowiek - Adam i którą miał on doprowadzić, w synergii jego wolnej woli z Bożą łaską, do doskonałości lub inaczej przebóstwienia. Oznacza to, że ludzka natura ma sens, który jest widoczny w jej ukierunkowaniu ku Bogu, by zgodnie z przeznaczeniem znaleźć w Nim swe spełnienie. Według prawosławnej antropologii, człowiek jest w stanie zdrowia wtedy, gdy realizuje swoje przeznaczenie i jego siły używane są zgodnie z tym naturalnym celem. Dlatego grzech pojmowany jako oddzielenie od Boga, oddala człowieka od tego głównego celu i wprowadza w nim wielopostaciowy stan choroby. Dzięki zaś ascezie stanowiącej prawosławną terapię, człowiek nawraca się ontologicznie, odwracając się od przeciwnego naturze patologicznego stanu i powraca do Boga odzyskując zdrowie swej natury ${ }^{5}$.

Rajski stan, w którym człowiek żył zgodnie z pierwotną naturą, jawi się więc jako stan zdrowia, kiedy to człowiek nie znał żadnej choroby zarówno duszy, jak i ciała, prowadząc życie całkowicie normalne, ponieważ zgodne z jego naturą i z prawdziwym jej celem 6 .

Stary Testament jako przyczynę chorób wskazuje też na brak umiarkowania: $Z$ przejedzenia powstaje choroba, a nieumiarkowanie powoduje rozstrój żoładka. Z przeje-

\footnotetext{
4 Zob. S. Rumiński, Religia pomaga w leczeniu, http://www.martyria. diecezja.elk.pl/cze_27.htm, (data dostępu 16.02.2018).

5 Zob. J.-C. Larchet, Terapia chorób duchowych. Wstęp do tradycji ascetycznej Kościoła prawosławnego, przeł. mniszka Nikołaja (Aleksiejuk), Hajnówka 2013, s. 10.

6 Zob. Tamże, s. 18.
}

dzenia wielu umarło, ale umiarkowany przedtuży swe życie (Syr 37,30-31).

Cierpienie pojawia się czasami także z dopustu Bożego, poprzez działanie złych mocy, tak jak w przypadku starotestamentowego Hioba: Rzekt Pan do szatana: Oto jest $w$ twojej mocy, tylko jego życie zachowaj. I odszedt szatan sprzed oblicza Pana, i dotknąt Hioba złośliwymi wrzodami od stóp aż do głowy (Hi 2,6-7).

Księga Mądrości Syracha przestrzega, by w chorobach swych szczególnie dbać o łączność z Bogiem i czystość swego serca: Synu, w chorobie swej nie odwracaj sie od Pana, ale módl się do Niego, a On cię uleczy. Usuń przewrotność - wyprostuj ręce i oczyść serce z wszelkiego grzechu! (Syr 38,9-10). Słowa zaś: Grzeszacy przeciw Stwórcy swemu niech wpadnie $w$ ręce lekarza $($ Syr 38,15) znaczą wprost - niech grzesznik zachoruje.

Chorobliwy stan upadku człowieka jest skutkiem faktu oddalenia się od Boga i utraty Jego łaski w wyniku czego natura ludzka doświadcza dysharmonii. Jej odnowienie według Ojców Kościoła możliwe jest jedynie na drodze ponownej integracji osoby ludzkiej w Chrystusie, będącym „,wzorem człowieka”. Aby człowiek mógł tego dokonać, musi żyć zgodnie z Duchem Świętym, prowadząc życie duchowe, gdyż: nikt nie może rzec: Jezus jest Panem, chyba tylko w Duchu Świętym (1 Kor 12,3).

Ojcowie Kościoła porównują zdrowie człowieka do stanu doskonałości ${ }^{7}$, do którego jest on przeznaczony ze względu na swą naturę. Św. Grzegorz Palamas twierdził, że zdrowiem i doskonałością duszy jest upodobnienie się do Chrystusa, osiągane za pośrednictwem miłości i przestrzegania przykazań Bożych ${ }^{8}$. Św. Symeon Nowy Teolog zwracał uwagę, że zdrowiem duszy jest przybycie i obecność w niej Ducha Świętego: kiedy On przychodzi, ponieważ wygania wszelką chorobę i ułomność w duszy, nazywa się Go zdrowiem, ponieważ daje nam zdrowie duszy 9 .

Św. Mikołaj Kabasilas stwierdza podobnie: w dniu, w którym Adam, zdając się na złego ducha, odwrócił się od swego dobrego Pana, jego dusza utraciła zdrowie i dobrobyt $^{10}$.

Św. Grzegorz z Nyssy w swym słowie o Modlitwie Pańskiej pisze: zdrowie duszy polega na postępowaniu zgodnym z wolą Bożą, i odwrotnie - utrata tej zgodności jest chorobą duszy prowadzącą do śmierci. Staliśmy się słabi, ponieważ utraciliśmy szczęśliwe życie w raju, kiedy wypiliśmy do ostatniej kropli szkodliwą truciznę nieposłuszeństwa. Naszą naturę opanowała wtedy ciężka i śmiertelna choroba. I oto przyszedł prawdziwy Lekarz. Miał nas wyleczyć ze zła za pomocą zupełnie innych środków niż te, które zaleca medycyna. Ponieważ ulegaliśmy słabości przez to, że przestaliśmy pełnić wolę Bożą, dlatego Bóg

\footnotetext{
Doskonałość oznacza dla Ojców Kościoła stan przebóstwienia natury ludzkiej łaską Bożą.

8 Św. Grzegorz Palamas, Triady, II, 1,42, https://azbyka.ru/otechnik/Grigorij_Palama/triady-v-zashhitu-svjashhenno-bezmolvstvujushhih/\#0_4, (data dostępu 02.05.2018).

9 Św. Symeon Nowy Teolog, Traktaty etyczne, VII, 359-361, [w:] J. C. Larchet, Terapia ..., dz. cyt. s. 29.

10 Św. Mikołaj Kabasilas, Życie w Chrystusie, II 38, http://aleteia.narod. $\mathrm{ru} /$ kavasila/7slov.htm\#2, (data dostępu 14.05.2018).
} 
uwalnia nas znowu od choroby i jednoczy ze Swoją wolą. Słowa modlitwy są terapią ducha! Leczą bowiem chorobę tkwiącą w naszej duszy. Kto przytłoczony jest cierpieniem tkwiącym w duszy, niech modli się słowami: „bądź wola Twoja". A wola Boża - jest zbawieniem ludzi" "11.

Życie pobożne, dzięki któremu człowiek dostępuje uświęcenia i zbawienia skutkuje też przywróceniem jego zdrowia. Człowiek święty jest zdrowy dlatego, że poprzez przywrócenie w sobie podobieństwa do pierwotnego piękna Bożego obrazu, staje się on zgodny z normą ludzkiej natury stworzonej przez Boga ${ }^{12}$.

Dlatego św. Ewagriusz z Pontu uważa „nieznajomość” Boga za najbardziej podstawową „,chorobę duszy” podczas gdy, na odwrót, ,"poznanie jest zdrowiem duszy”"13.

Używany w Nowym Testamencie czasownik zbawiać oznacza nie tylko ocalić, albo wyciągnąć z niebezpieczeństwa, ale również uzdrowić, a słowo: zbawienie oznacza nie tylko ocalenie, ale i uzdrowienie. Samo imię Jezus oznacza: „Jahwe zbawia”"14, a inaczej mówiąc „uzdrawia"15. Jezus Chrystus często też przedstawia Siebie, jako lekarza, mówiąc: Nie potrzebuja lekarza zdrowi. Lecz ci, którzy się źle maja (...). Nie przyszedtem powolać sprawiedliwych, ale grzeszników (Mt 9,2-13). Dlatego słowa: twoja wiara cię uzdrowiła (Łk 17,19), należy rozumieć jako równoznaczne $\mathrm{z}$,twoja wiara cię zbawiła”, gdyż oba te wyrażenia mówią o akcie Bożego przebaczenia dotyczącym duszy i ciała $\mathrm{w}$ ich jedności ${ }^{16}$.

Św. Ignacy z Antiochii pisze do Efezjan: Jeden jest Lekarz, cielesny i duchowy zarazem, zrodzony i niezrodzony, przychodzący w ciele Bóg, w śmierci życie prawdziwe, zrodzony z Maryi i zrodzony z Boga (...) nasz Pan ${ }^{17}$. Św. Justyn mówi o Chrystusie: Dla nas stał się On człowiekiem, by mieć udział w naszych cierpieniach i je uleczyćc ${ }^{18}$. Św. Grzegorz z Nyssy z kolei twierdzi: Prawdziwy Lekarz dusz wszedłszy z miłości ku chorym w ludzkie życie, nauką o modlitwie usuwa chorobę i przywraca zdrowie naszej duszy ${ }^{19}$.

Chrześcijański sposób przeżywania chorób cechuje pokora, cierpliwość oraz pokładanie nadziei w Bogu i Jego łaskawej woli. Takie podejście i modlitwa wzmacnia chorego, dzięki czemu może on, nie popadając w stany złości,

\footnotetext{
1 Św. Grzegorz z Nyssy, O molitwie, IV, Moskwa 1999, s. 55.

12 Por. J.-C. Larchet, Terapia ..., dz. cyt. s. 703.

13 Św. Ewagriusz, Podstawowe zagadnienia gnostyckie. II, 8, [w:] J. C. Larchet, Terapia ...,dz. cyt. s. 42.

14 Por. Mt 1,21: Porodzi Syna, któremu nadasz imię Jezus, On bowiem zbawi swój lud od jego grzechów. Dz 4,12: I nie ma w żadnym innym zbawienia, gdyż nie dano ludziom pod niebem żadnego innego imienia, w którym moglibyśmy być zbawieni.

15 Podwójne znaczenie można znaleźć także w języku koptyjskim oraz włoskim, gdzie la salute oznacza jednocześnie ,zbawienie” i ,zdrowie”, zob. J. C. Larchet, dz. cyt. s. 6-7, por. przyp. 7, tamże, s. 7.

16 Zob. P. Evdokimov, Prawosławna wizja teologii moralnej..., dz. cyt., s. 87 .

17 Św. Ignacy Antiocheński, Ignacy do Kościoła w Efezie, [w:] Pierwsi świadkowie: pisma Ojców Apostolskich, przeł. A. Świderkówna, Kraków 1998, s. 115.

18 Św. Justyn Męczennik, Apologia pierwsza. Apologia Druga, [w:] Pierwsi apologeci greccy, przeł. L. Misiarczyk, red. J. Naumowicz, Kraków 2004, s. 281.

19 Św. Grzegorz z Nyssy, O molitwie, IV, Moskwa 1999, s. 55.
}

goryczy, buntu i rozpaczy, zachowywać wewnętrzny spokój. Wiara pomaga zrozumieć i nadać sens chorobie. Ukazuje ona też sposób przeżywania cierpienia, który przynosi ukojenie. Człowiek wierzący powinien postrzegać okres utraty zdrowia jako czas próby i nawrócenia, w którym drogą pokajania może zbliżyć się do Boga.

Dzięki swej pobożności wierzący łatwiej przyjmują chorobę i jej skutki. Potrafią świadomie pogodzić się z zaistniałą sytuacją, gdyż wierzą, że to co przeżywają wpisuje się w plan ich zbawienia - musimy przejść przez wiele ucisków, aby wejść do Królestwa Bożego. (Dz 14,22). Chrześcijaństwo nie stara się odpowiedzieć choremu na pytanie dlaczego cierpi, lecz próbuje nadać sens temu cierpieniu, czyniąc je wartościowym. Sprawia, że choroba będąca stratą, może okazać się dla człowieka zyskiem.

Dla chrześcijanina, cielesne zdrowie nie jest jednak wartością główną i najważniejszą. Jest ono wtórne w stosunku do zdrowia duchowego, dlatego przez wielu Ojców Kościoła choroba fizyczna postrzegana była często jako sposób na osiągnięcie zdrowia duchowego. Zwracali oni uwagę, że choroba może mieć pozytywny, terapeutyczny wpływ na człowieka, gdyż dzięki niej, chory odnajduje drogę ku Bogu, zaczyna bardziej zastanawiać się nad sensem życia, myśleć o swym zbawieniu, uczy się pokory, cierpliwości i modlitwy.

Głębszy sens choroby polega na uświadomieniu człowiekowi tego, co jest niezbędne dla jego powrotu do zdrowia, czyli harmonii. Choroba domaga się, aby wsłuchać się w siebie, w głos swojego prawdziwego ja i zmienić swój sposób postępowania, zanim będzie za późno. Prawdziwe leczenie nie ma na celu usunięcia symptomów przy jednoczesnym pozostawieniu ich przyczyny, lecz polega na świadomym rozpoznaniu sfery zakłóceń harmonii w organizmie i przywróceniu jej do stanu pierwotnego. Uzdrowienie zależy od tego, czy człowiek zrozumie, co chce mu przekazać jego choroba oraz od tego, czy posłucha tego przesłania. Powrót do harmonii (zdrowia) jest uwarunkowany uporządkowaniem myśli, uczuć, mowy i czynów ${ }^{20}$.

Choroba uzewnętrznia się poprzez informacje przekazywane za pośrednictwem ciała. Symptomy choroby dostrzegalne są np. w wyglądzie, ogólnej kondycji fizycznej i sprawności psychicznej. Każda dolegliwość jest komunikatem, który należy odczytać i zinterpretować na płaszczyźnie somatycznej, psychicznej i duchowej. Następnie dokonując syntezy wniosków powstałych z tej analizy, możliwym jest określenie stanu zdrowia człowieka i wyznaczenie sposobu postępowania $w$ leczeniu.

Ten kto ukrywa swój grzech, akceptuje jego szkodliwe działanie w duszy. Według św. Kasjana, myśli ukryte niszczą serce i doprowadzają do chorób ${ }^{21}$.

Św. Bazyli Wielki napomina, że niewłaściwym jest uleganie fałszywemu przekonaniu, że każda choroba wymaga pomocy medycznej, ponieważ nie wszystkie choroby wynikają z jakichś zaburzeń w naszej naturze, lecz

\footnotetext{
20 Zob. K. Tepperwein, Co choroba mówi o tobie, Katowice 2003, s. 1920.

${ }_{21}$ Zob. Ks. K. Gryz, Antropologia przebóstwienia. Obraz człowieka w teologii prawosławnej, Kraków 2009, s. 344.
} 
występują czasami jako skutek złego stylu życia i naszych grzesznych decyzji, dlatego często choroby są karą za grzechy, w celu naszego pobudzenia ku nawróceniu ${ }^{22}$ : Czemu krzyczysz z powodu swojej rany, że dotkliwy jest twój ból? Za wielka twoja wine ci to uczynitem, za to, że liczne sa twoje grzechy (Jer 30,15).

Choroba powinna stać się okazją do spotkania i komunikacji z Bogiem oraz bliźnimi. Ludzie przeżywający cierpienia, gorliwiej dbają o swoje zdrowie duchowe: Jeżeli pilnie stuchać będziesz głosu Pana, Boga twego i czynić będziesz to, co prawe w oczach jego, i jeżeli zważać będziesz na przykazania jego, i strzec będziesz wszystkich przepisów jego, to żadna choroba, która dotknatem Egipt, nie dotknę ciebie, bom Ja, Pan, twój lekarz (Wj 15,26). Doświadczenie choroby sprzyja uświadomieniu własnej grzeszności. Poprzez pokajanie, spowiedź, duchowe doskonalenie się i dobre uczynki, ludzie wierzący zyskują łaskę Bożą i siły duchowe potrzebne do pokonania choroby.

Chory człowiek jeśli jest wierzący, to zachowując właściwą postawę religijną wobec życia, swoją sytuację podczas choroby stara się postrzegać jako „wolę Bożą", niesienie „Krzyża Chrystusowego”, znak szczególnej troski Bożej. Z prawosławnej perspektywy życia religijnego, chorobę interpretuje się jako doświadczenie miłości Bożej, zgodnie ze słowami: Bo kogo Pan mituje, tego karze. I chłoszcze każdego syna, którego przyjmuje (Hbr 12,6). To duchowe doświadczenie ma znaczenie dla jego osobistego zbawienia, gdyż może posłużyć większemu zbliżeniu się do Boga.

Św. Ignacy Branczaninow pisał, że łoże choroby bywa często miejscem poznania Boga i siebie samego ${ }^{23}$. Wierzący człowiek nie stoi w miejscu, zatrzymany problemem choroby. Pomimo tego co się mu przytrafiło nie traci on sensu w życiu, lecz stara się go bardziej zrozumiećc ${ }^{24}$. Posiada silnie sprecyzowany cel główny, którym jest dążenie do życia wiecznego. Chorobę postrzega więc jako

\footnotetext{
22 Zob. Św. Bazyli Wielki, [w:] Tworenija iże wo swiatych otca naszego Wasilija Wielikogo, archijepiskopa Kiesarii Kappadokijskoj, t. 5, Siergijew Posad 1901, s. 172.

${ }_{23}$ Św. Ignatij Branczaninow, Pisma k mirianam, $\mathrm{Nr} 225$, [w:] Sobranije pisiem swiatitiela Ignatija jepiskopa kawkazskogo, Moskwa-S. Petersburg 1995, s. 432

24 Jezus na pytanie uczniów o niewidomego od urodzenia (J 9,2-3): Kto zgrzeszyt - on, czy rodzice jego? - odpowiada: ani on nie zgrzeszyl, ani rodzice jego, ale stało się tak, aby na nim objawity się dzieła Boże. W tym przypadku Jezus daje nam do zrozumienia, że przez każde cierpienie Bóg nas do czegoś wzywa i coś nam objawia, dlatego stosownym byłoby szukanie odpowiedzi na pytanie: co Bóg chce nam powiedzieć poprzez to cierpienie i czego w ten sposób chce nauczyć?
}

zdarzenie, które spotyka na swej drodze i musi pokonać dzięki cierpliwości, pokorze oraz miłości. Ufając Bogu, przyjmuje chorobę jako próbę i sprawdzian swej pobożności. Osobiste cierpienie staje się świadectwem jego wiary, która z pomocą Bożą odnosi zwycięstwo, stając się częścią paschalnego triumfu życia nad śmiercią i dobra nad złem. Religijne przeświadczenie o sensie swego losu ma silny terapeutyczny wpływ na proces odzyskiwania zdrowia. Pozwala człowiekowi trwać w chorobie i znosić jej trudy, wykorzystując ją ku duchowemu wzrastaniu. Nie załamując się i nie popadając w rozpacz osoba taka pozytywnie, z nadzieją interpretuje wszystko co ją spotyka.

Choroby sprawiają, że człowiek narusza swą osobistą, życiową stabilizację i może w tym stanie doświadczać kryzysu oraz utraty sensu życia. Dlatego każda choroba ma bardzo ważny kontekst religijny. Jej znaczenie należy więc postrzegać w perspektywie zbawienia człowieka, pamiętając w chwilach próby, że: Bóg jest wierny i nie dopuści, abyście byli kuszeni ponad sity wasze, ale z pokuszeniem da i wyjście, abyście je mogli znieść (1 Kor 10,13).

Nie ma człowieka na ziemi, któremu nie dane byłoby doświadczyć cierpienia. Ono towarzyszy mu od samego początku jego życia. Wraz z chorobami jest jednym ze skutków grzechu pierworodnego. Jeśli człowiek potrafi przyjmować je z pokorą, to może ono przyczynić się ku duchowej przemianie, oczyszczeniu z grzechów i moralnemu rozwojowi oraz zbliżeniu się do Boga.

Dążenie do zdrowia i dbanie o zdrowie, wpisują się w cały szereg ludzkich działań, zmierzających do zapewnienia długiego i pomyślnego życia. Być zdrowym, to znaczy być scalonym ${ }^{25}$, czyli w pełni sobą w jedności i harmonii swej natury. Dopóki tego scalenia nie ma, nie można mówić o pełni zdrowia, gdyż człowiek nieustannie doświadcza w swym życiu różnorodnych stanów dezintegracji, np. może być fizycznie chory, a psychicznie i duchowo stabilny. Może również mieć różnego rodzaju problemy psychiczne, np. chorując na depresję lub schizofrenię, a mimo to prowadzić całkowicie poprawne życie duchowe. Podobnie jak człowiek psychicznie i fizycznie będąc formalnie zdrowym, może doświadczać wielu problemów duchowych.

Stan zdrowia jest więc celem osiągalnym dopiero w perspektywie wieczności i jako taki powinien być przedmiotem zaangażowania i nieustannej troski wszystkich ludzi.

\footnotetext{
25 Zdrowy w języku cerkiewnosłowiańskim znaczy „cełyj”, czyli: cały,
} zjednoczony, zintegrowany, zharmonizowany.

\section{Bibliografia}

Bazyli Wielki, Tworenija iże wo swiatych otca naszego Wasilija Wielikogo, archijepiskopa Kiesarii Kappadokijskoj, t. 5, Siergijew Posad 1901.

Fijałek Jan, Społeczne tradycje organizacyjne i naukowe w opiece zdrowotnej do końca XVIII wieku, [w:] Historia medycyny, T. Brzeziński (red.), , Warszawa 1995.

Gryz Krzysztof, ks., Antropologia przebóstwienia. Obraz człowieka w teologii prawosławnej, Kraków 2009. 
Grzegorz z Nyssy, O molitwie, IV, Moskwa 1999.

Ignacy Antiocheński, Ignacy do Kościoła w Efezie, [w:] Pierwsi świadkowie: pisma Ojców Apostolskich, przeł. A. Świderkówna, Kraków 1998.

Justyn Męczennik, Apologia pierwsza. Apologia Druga, [w:] Pierwsi apologeci greccy, przeł. L. Misiarczyk, red. J. Naumowicz, Kraków 2004.

Karwat Irena D. i in., Zdrowie i niepetnosprawność - problemy $w$ definiowaniu. Cz. 1. Cechy wykorzystywane $w$ ocenie stanu zdrowia, „Journal of Health Sciences” 2012; (2)5.

Kurt Tepperwein, Co choroba mówi o tobie, Katowice 2003.

Larchet Jean-Claude, Terapia chorób duchowych. Wstęp do tradycji ascetycznej Kościoła prawosławnego, przeł. mniszka Nikołaja (Aleksiejuk), Hajnówka 2013.
Mikołaj Kabasilas, Życie w Chrystusie, II 38, http://aleteia.narod. ru/kavasila/7slov.htm\#2, (data dostępu 14.05.2018).

Paul Evdokimov, Prawosławna wizja teologii moralnej. Bóg w życiu ludzi, przeł. W. Szymona OP, Kraków 2012.

Rożniatowski Tadeusz, Mała encyklopedia medycyny, Warszawa 1982.

Rumiński Stanisław, Religia pomaga w leczeniu, http://www.martyria.diecezja.elk.pl/cze_27.htm, (data dostępu 16.02.2018).

Św. Grzegorz Palamas, Triady, II, 1,42, http://www.biblicalstudies.ru/Lib/Father914/GrPalama9.html, (data dostępu 02.05. 2018).

Św. Ignatij Branczaninow, Sobranije pisiem swiatitiela Ignatija jepiskopa kawkazskogo, Moskwa-S. Petersburg 1995.

Teofan Zatwornik, Czto jest'duchownaja żyzń i kak na jeje nastroitsa?, Moskwa 2001.

Rozmiar artykułu: 0,6 arkusza wydawniczego 


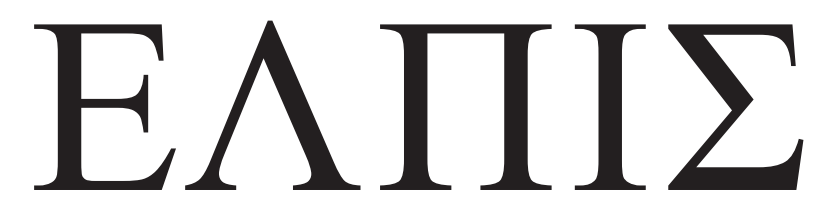

CZASOPISMO TEOLOGICZNE KATEDRY TEOLOGII PRAWOSŁAWNEJ UNIWERSYTETU W BIAŁYMSTOKU

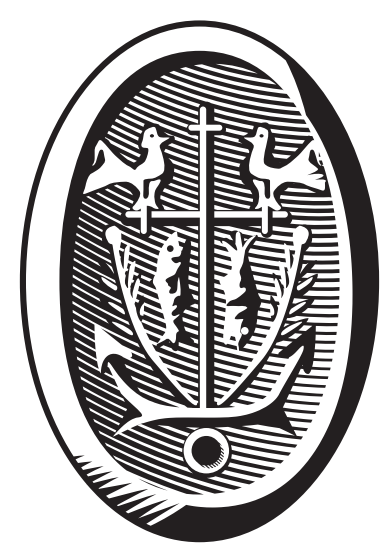

ADRES REDAKCJI

ul. Ludwika Zamenhofa 15, 15-435 Białystok, Polska tel. 85 745-77-80, e-mail: elpis@uwb.edu.pl www.elpis.uwb.edu.pl 